\title{
Biodegradable Plastic Mulch for Water Conservation in Horticultural Crops
}

\author{
S. Ahirwar*, M.K. Tiwari, G. Namwade and S. Bhukya \\ College of Agricultural Engineering and Technology, Anand Agricultural University, \\ Godhra, Gujarat-389001, India \\ *Corresponding author
}

\section{A B S T R A C T}

\section{Keywords}

Plastic mulch, Biodegradable plastic mulch,

Water use efficiency

Article Info

Accepted:

15 January 2019

Available Online:

10 February 2019
Water is the elixir of life, precise and efficient use of this elixir is very crucial and utmost important in the busy and clutter life. Agricultural sector is the greater consumer of water. Use of plastic mulch in agriculture sector increases water use efficiency but problem is that removal from field after use. Biodegradable plastic mulch offers an environmentally sustainable alternative to conventional polyethylene mulch. In this paper, types of mulch, importance of biodegradable plastic mulch, comparison between biodegradable plastic mulch over different mulches, effect of temperature, evaporation, reduces weed growth, conserve soil moisture and effect on yield are reviewed.

\section{Introduction}

Water is the elixir of life, precise and efficient use of this elixir is very crucial and utmost important in the busy and clutter life. Agricultural sector is the greater consumer of water. Agriculture accounts for $70 \%$ of all water withdrawals globally. Irrigated land is more than twice as productive as rain-fed cropland (World Bank, 2017).

Use of mulch in agriculture field conserve moisture, reduce weed growth and maintain temperature which are favourable to plant growth and production. Mulch is a layer of material applied to the surface of an area of soil to control weeds, conserve soil moisture (reducing evaporation) and to regulate soil temperature in favor of crop production. It may be permanent or temporary. It may be applied to bare soil, or around existing plants.

Mulches of manure or compost will be incorporated naturally into the soil by the activity of worms and other organisms. The process is used both in commercial crop production and in gardening, and when applied correctly can dramatically improve soil productivity. 


\section{Benefits}

Improve soil moisture.

Moderates soil temperature.

Reduced weed problems.

Black plastic mulch provides good weed control in the row. Clear plastic will require use of herbicide. Often, weeds between mulch strips can be controlled by herbicide.

Reduced leaching of fertilizers

Water runs off the impervious mulch, resulting in maximum utilization of the fertilizer.

Earlier crop production ( 7 to $21 \mathrm{~d}$ earlier in the field).

Higher yields per unit area ( 2 to 3 times higher).

Plastic mulch is practically impervious to carbon dioxide, a gas that is of prime importance in photosynthesis. Very high levels of carbon dioxide build up under the plastic, because the film does not allow it to escape. It has to come through the holes made in plastic for the plants and a "chimney effect" is created, resulting in localized concentrations of abundant carbon dioxide for actively growing leaves.

\section{Classification of mulches}

Advancement in plastic chemistry has resulted in development of films with optical properties that are ideal for a specific crop in a given location. Horticulturists need to understand the optimum above and below ground environment of a particular crop before the use of plastic mulch. These are two types.

\section{Photo-degradable plastic mulch}

This type of plastic mulch film gets destroyed by sun light in a shorter period.

\section{Bio-degradable plastic mulch}

This type of plastic mulch film is easily degraded in the soil over a period of time.

\section{Color of film}

Soil environment can be managed precisely by a proper selection of plastic mulch composition, color and thickness. Films are available in variety of colors including black, transparent, white, silver, blue red, etc. But the selection of the color of plastic mulch film depends on specific targets. Generally, the following types of plastic mulch films are used in horticultural crops.

Black plastic film: It helps in conserving moisture, controlling weed and reducing outgoing radiation.

Reflective silver film: It generally maintains the root-zone temperature cooler.

Transparent film: It increases the soil temperature and preferably used for solarization.

Apart from the above classification there is another way of classifying Methods in mulching:

Surface Mulching: Mulches are spread on surface to reduce evaporation and increase soil moisture.

Vertical Mulching: It involves opening of trenches of $30 \mathrm{~cm}$ depth and $15 \mathrm{~cm}$ width across the slope at vertical interval of $30 \mathrm{~cm}$.

Polythene Mulching: Sheets of plastic are spread on the soil surface between the crop rows or around tree trunks.

Pebble Mulching: Soil is covered with pebbles to prevent transfer of heat from atmosphere.

Dust Mulching: Interculture operation that creates dust to break continuous capillaries, and deep and wide cracks thus reducing evaporation from the exposed soil areas. 
Live Vegetative Barriers on contour key lines not only serve as effective mulch when cut and spread on ground surface, but also supply nitrogen to the extent of 25 to $30 \mathrm{~kg}$ per ha, besides improving soil moisture status.

\section{Why farmers are using plastic mulch?}

Because main reason is, it prevent weed growth-

In 1 acre farm 3 times weeding operation is require and in 1 time weeding operation require 4 man days and labour cost is $300 ₹$ per day means total cost $3600 ₹$ is require. So by the use of plastic mulching cost of weeding could be eliminated.

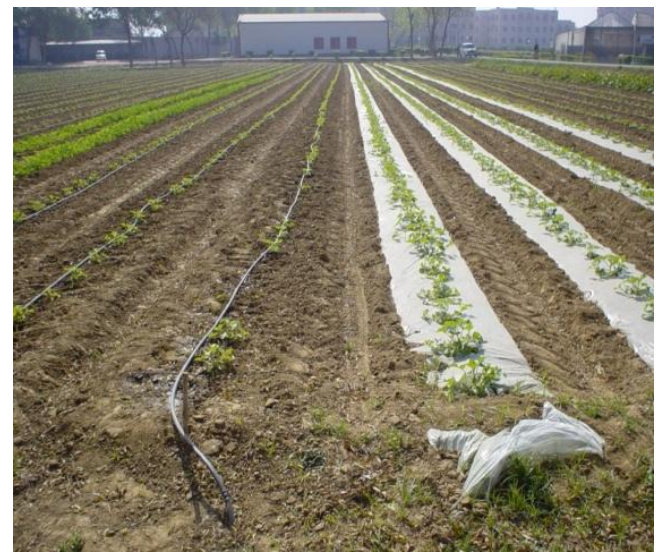

Picture.1 Effect of Plastic Mulching in the Drip Irrigated Vegetable Crop

Growth of plants under plastic mulch and in bare soil.

\section{Non degradable plastic mulch}

Main problem of plastic mulches are it is non degradable after the use of plastic mulches it form the residue in the field which needs to be removed. If burning the plastic mulch it produces the harmful gas in the air and pollutes the environment and as a land fill it obstruct for infiltration and percolation of water in ground.

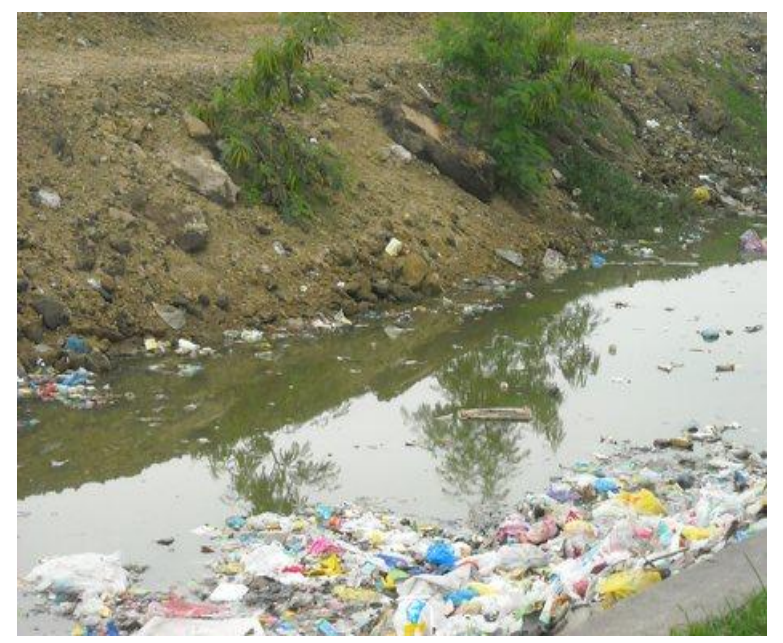

Picture.2 Non degradable plastics

If it is not dispose properly it cause soil pollution, pollution of the water bodies and ultimately it reaches in nallas, lacks and rivers which is the major problem now a day.

In order to avoid these problems biodegradable plastic mulches provides better alternatives.

\section{Biodegradable plastic mulch}

Mid-1970's British and American scientists discover biodegradable plastic derived from corn starch. Biodegradable mulch films are now becoming available, may be made from renewable resources, and are converted through microbial activity in the soil to $\mathrm{CO} 2$, water and natural substances, eliminating the need for pick up and disposal at the end of the season. Biodegradable plastics, as defined by the American Society for Testing and Materials, are "degradable plastic in which the degradation results from the action of naturally occurring microorganisms such as bacteria, fungi and algae" (Mooney, 2009).

It is the intrinsic chemical structure of the polymer that makes it biodegradable. To be biodegradable, some parts of the polymer main chain must be similar to naturally occurring substances; therefore, microbes can 
use their existing enzymes to break the polymer chain at those specific locations and use them as a source of energy. For example, microorganisms break down starch to use the glucose, which is broken down to two molecules of pyruvic acid, which can be further fermented into lactic acid or aerobically converted into $\mathrm{CO}$ to generate energy. Portions of polymers that are small enough are transferred into microbial cells and consumed as a food source.

Biodegradation is governed by different factors that include polymer characteristics, type of organism, and nature of pretreatment. The polymer characteristics such as its mobility, tacticity, crystallinity, molecular weight, type of functional groups and substituents present in its structure, and plasticizers or additives added to the polymer all play an important role in its degradation. During degradation, exoenzymes from microorganisms break down complex polymers yielding smaller molecules of short chains, e.g., oligomers, dimers, and monomers, that are smaller enough to pass the semi-permeable outer bacterial membranes and then to be utilized as carbon and energy sources. The process is called depolymerization. When the end products are $\mathrm{CO}, \mathrm{HO}$, or $\mathrm{CH}$, the degradation is called mineralization.

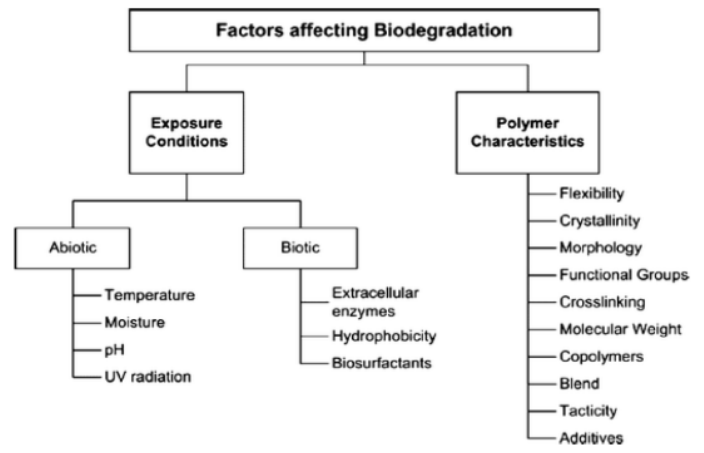

Figure.1 Factors affecting biodegradation

During degradation, the polymer is first converted to its monomers, and then these monomers are mineralized. Most polymers are too large to pass through cellular membranes, so they must first be depolymerized to smaller monomers before they can be absorbed and biodegraded within microbial cells. The initial breakdown of a polymer can result from a variety of physical and biological forces. Physical forces, such as heating/cooling, freezing/thawing, or wetting/drying, can cause mechanical damage such as the cracking of polymeric materials The biodegradation process begins once the biodegradable material is in increased contact with microorganism-rich environments, such as after plowing (soil burial) or in a compost pile. Microorganisms such as bacteria, fungi, and algae degrade the film by using it as their food source. Carbon removal from a starch polyethylene blend was low compared to pure starch, and the rate of removal was higher under aerobic conditions.

\section{How biodegradable plastic mulches are made?}

Two polymers that may have a role in biodegradable plastic mulches in the future are polylactic acid (PLA) and polyhydroxyalkanoate (PHA). PLA is highly versatile, biodegradable polyester derived from $100 \%$ renewable resources such as corn and sugar beet starch, and offers great promise in a wide range of commodity applications. Starch is converted by microorganisms into lactic acid through fermentation. Lactic acid molecules are then linked together into long chains called polymers. PHA polymers may be produced from microbes or plants, but currently, microbes are the primary source. Nonwovens are manufactured sheets, webs or bats of directionally or randomly oriented fibers or filaments, bonded together. Nonwovens may be manufactured by spunbond or meltblown processes. In the spunbond process, polymers are first melted and then extruded through spinnerets, producing filaments which are 
cooled and laid down on a conveyer belt to form a web. In the meltblown process, polymers are extruded through a die or spinneret, and filaments are stretched, dispersed, cooled, and then collected on a roll.

\section{Grower considerations}

Degrades in field - no retrieval

Various colors are available in biodegradable film

In biodegradable plastic mulches are higher product cost compared to nondegradable mulches

Biodegradable plastic mulches are available in various width - 3' to 5'.

Effect of biodegradable plastic mulch compare to non degradable plastic mulch: On soil temperature (Incalcaterra et al., 2004)

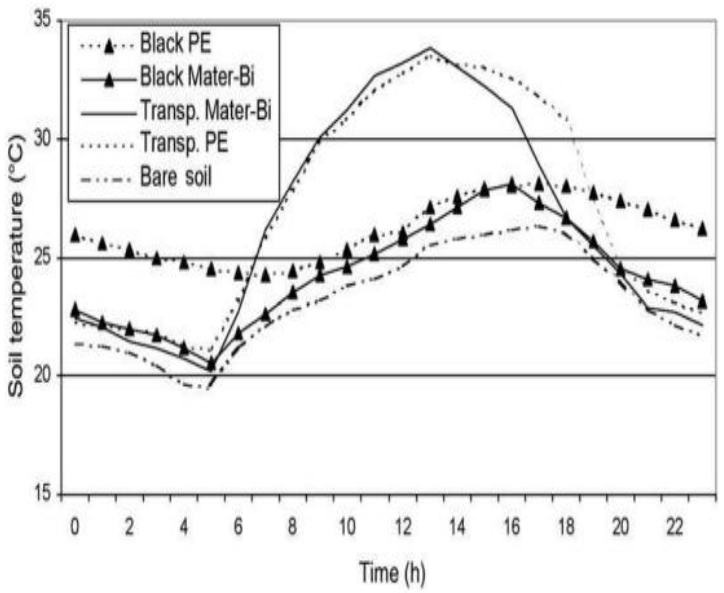

Figure.2 Diurnal patterns of soil temperature at the $5 \mathrm{~cm}$ depth. Data are shown for each of the plastic mulches and the bare soil plot

All mulches increased soil temperatures in comparison to the bare soil plots (Fig. 2). Maximum soil temperatures (ranging from 25.8 to $33.8{ }^{\circ} \mathrm{C}$ ) were measured under transparent $\mathrm{PE}$ and transparent biodegradable Mater-Bi films between 7:00 and 17:00 h. During this day period soil temperatures of these plots were from 3.7 to $8.6{ }^{\circ} \mathrm{C}$ higher than those in the bare soil. Night and predawn soil temperatures in the soil plots covered with black PE film were higher (from 4.2 to $5.5^{\circ} \mathrm{C}$ ) than those in the bare soil. Whereas, during the same day periods, soil temperatures in the transparent $\mathrm{PE}$ film plots were from 0.9 to $1.6{ }^{\circ} \mathrm{C}$ higher than those in the bare soil. Pre-dawn soil temperatures in the plots covered with transparent or black biodegradable Mater-Bi films, although higher than those in the bare soil were much lower than those under black PE film and comparable to those measured in the transparent PE plots.

Black PE film has a high short wave absorbance; the incoming radiation is first absorbed by the plastic and then transmitted to the soil by conduction. We can speculate that in absence of solar radiation, heat loss due to long wave infrared radiation was higher in the plots covered with black and transparent Mater- $\mathrm{Bi}^{\mathrm{TM}}$ films, and transparent $\mathrm{PE}$ as compared to that of black PE film. All mulches induced an earlier plant emergence (about 4 days) in comparison to bare soil plots.

Effect of soil cover on maximum, minimum and average soil temperature $\left({ }^{\circ} \mathrm{c}\right)$ at $5 \mathrm{~cm}$ depth (Bell Pepper) (June 4 - July 10) (Warner et al., 2010)

\begin{tabular}{|l|l|l|l|}
\hline Soil Cover & $\begin{array}{l}\text { Mean Maximum } \\
\text { Temperature }\end{array}$ & $\begin{array}{l}\text { Mean Minimun } \\
\text { Temperature }\end{array}$ & $\begin{array}{l}\text { Average } \\
\text { Temperat } \\
\text { ure }\end{array}$ \\
\hline Bare Soil & 27.8 & 16.8 & 21.8 \\
\hline $\begin{array}{l}\text { Black } \\
\text { Plastic(non } \\
\text { degradable) }\end{array}$ & 29.6 & 19.2 & 23.9 \\
\hline $\begin{array}{l}\text { Biolene } \\
\text { Biodegrad } \\
\text { able) }\end{array}$ & 29.2 & 19.2 & 23.8 \\
\hline
\end{tabular}

Biodegradable plastic mulches are not significantly different from black plastic mulch but it is significantly different from the bare soil. 


\section{Effect on yield}

\begin{tabular}{|l|l|l|}
\hline Mulch & $\begin{array}{l}\text { Early } \\
\text { Marketable } \\
\text { Yield (Tonnes } \\
\text { ha) }\end{array}$ & $\begin{array}{l}\text { Total Yield } \\
\text { (Tonnes/ha) }\end{array}$ \\
\hline Melon & 15.9 \\
\hline Bare Soil & 2.4 & 20.0 \\
\hline $\begin{array}{l}\text { Black Plastic } \\
\text { Mulch }\end{array}$ & 16.8 & 19.2 \\
\hline Biodegradable & 17.2 & 52.9 \\
\hline Bell Pepper & \multicolumn{2}{|l|}{} \\
\hline Bare Soil & 38.2 & 49.5 \\
\hline Black Plastic & 39.1 & 45.8 \\
\hline Biodegradable & 37.7 & 2.8 \\
\hline Broccoli & 1.6 & 4.3 \\
\hline Bare Soil & 3.7 & 3.5 \\
\hline Black Plastic & 2.7 & \\
\hline Biodegradable & & \\
\hline
\end{tabular}

All mulches markedly increased early and total yields in comparison to unmulched plots. The higher soil temperatures produced by the transparent films in combination with the use to maximize available water resources, played a major role in increasing early melon, bell pepper and broccoli and total yields. In this study transparent PE (non degradable) mulch and transparent Mater-Bi ${ }^{\mathrm{TM}}$ (bio degradable) mulch had similar marketable early and total yields. The Mater-Bi film adds the advantage of rapid degradation to many of the desirable effects of plastic mulch and therefore, it represents an environmentally friendly alternative to PE film mulching.

\section{Water-saving mechanism and enhancement of efficiency with mulching}

Mulching materials and techniques significantly affect the microclimate around the crop canopy by changing the radiation budget of the soil top, soil water transformation, aerodynamic properties, and soil temperature so as to influence the crop yield $(Y)$, evapotranspiration (ET), and water use efficiency (WUE). WUE $\left(\mathrm{kg} / \mathrm{m}^{3}\right)$ was calculated as the grain yield $\left(\mathrm{kg} / \mathrm{hm}^{2}\right)$ divided by the total ET (mm) from sowing to harvest.

$\mathrm{WUE}=\frac{Y}{\int_{\text {sowing }}^{\text {harvest }} \mathrm{ET} \cdot \mathrm{d} t}$

Water use efficiency for Maize Crop (Yang et al., 2015)

\begin{tabular}{|l|l|}
\hline Mulching material & WUE $\left(\mathbf{k g} / \mathbf{m}^{\mathbf{3}}\right)$ \\
\hline Bare soil & 2.50 \\
\hline Black plastic mulch & 3.27 \\
\hline $\begin{array}{l}\text { Biodegradable plastic } \\
\text { mulch }\end{array}$ & 3.25 \\
\hline
\end{tabular}

Water use efficiency of biodegradable plastic mulch is similar to that of black plastic mulch but it is significantly different from bare soil.

Effect of type of mulch on soil cover rating for various dates (Warner et al., 2010)

\begin{tabular}{|l|l|l|}
\hline & Bio-lene & Black plastic \\
\hline Jun 11 & 1 & 0 \\
\hline Jun 23 & 1 & 0 \\
\hline Jul 08 & 1 & 0 \\
\hline Jul 22 & 1 & 0 \\
\hline Jul 30 & 1.3 & 0 \\
\hline Aug 14 & 2.3 & 0 \\
\hline Aug 30 & 2.3 & 0 \\
\hline Sep 13 & 3 & 0 \\
\hline Oct 01 & 4.5 & 0 \\
\hline
\end{tabular}

0 to 5 rating (rated every 2 weeks):

$0=$ no breakdown of mulch, $100 \%$ soil cover. $1=$ small holes forming in mulch, nearly $100 \%$ soil cover. 
$2=$ one or more small tears over $30 \mathrm{~cm}$ long, $>90 \%$ soil cover.

$3=$ multiple tears and holes in mulch, 75 to $90 \%$ soil cover.

$4=$ multiple tears and holes, 50 to $75 \%$ soil cover.

$5=$ mulch largely deteriorated, $<50 \%$ soil cover.

The conclusions of the study are as follows

Increase in soil temperature under biodegradable plastic mulch $\left(23.8^{\circ} \mathrm{C}\right)$ is almost equal to that under non-degradable plastic mulch $\left(23.9^{\circ} \mathrm{C}\right)$. No significant difference was observed for total and marketable yield over the season. In case of effect on early yield, Bell pepper has no effect but Melon increases (4 days early emergence) Not significant difference was observed in water use efficiency. Biodegradable plastic mulch $\left(3.25 \mathrm{kgm}^{-3}\right)$ and non degradable plastic mulch $\left(3.27 \mathrm{kgm}^{-3}\right)$ was observed.

The performances of biodegradable plastic mulch is similar to black polyethylene mulch but with an advantage that field removal of the biodegradable films are not required at the end of the season. It starts to degrade in about 45 to 50 days after laying the mulch except Green plastic (biodegradable) Mulch.

\section{References}

Incalcaterra, G., Sciortino, A., Vetrano, F., and Lapichino, G., (2004). Agronomic response of Water Melon (Cucumis melo inodorus Noud.) to biodegradable and polyethylene film mulches, and to different plant densities. Mediterranean rainfed Agriculture: strategies for sustainability. 60: 181-184.

López-Marin, J., Fernández, J. A., Pablos, J. L. and Abrusci, C. (2012) Biodegradable Mulch Film in a Broccoli Production System. Acta Hort. 933: 439-444.

López, J., González, A., Fernández, J.A. and Bañón, S. (2007). Behaviour of biodegradable films for mulching in melon cultivation. Acta Hort. 747: 125130.

Mooney, B. P. (2009). The second green revolution? Production of plant-based biodegradable plastics. Biochemical Journal, 418(2), 219-232.

Warner, J. and Zandstra, J. (2010). Biodegradable Polymer Mulches in Bell Pepper Production. Agriculture and Agri-Food 23: 151-163.

Yang, N., Sun, Z., Feng, L., Zheng, M., Chi, D., Meng, W., Hou, Z., Bai, W., and Li, K. (2015) Plastic film mulching for water-efficient agricultural applications and degradable films materials development research. Agricultural Engineering. 30(2), 143-154.

\section{How to cite this article:}

Ahirwar, S., M.K. Tiwari, G. Namwade and Bhukya, S. 2019. Biodegradable Plastic Mulch for Water Conservation in Horticultural Crops. Int.J.Curr.Microbiol.App.Sci. 8(02): 1731-1737. doi: https://doi.org/10.20546/ijcmas.2019.802.204 